\title{
The Innovation of Learning Media in Web-Based Dance Teaching Techniques in Dance Education FBS UNIMED Students
}

\author{
Tuti Rahayu ${ }^{1}$ \\ \{tutirahayu12@gmail.com \} \\ Faculty of Language and Art, State University of Medan \\ Departement of Dance, Indonesia ${ }^{1}$
}

\begin{abstract}
Nias Dance Technique is one of the courses which are included in the presentation group, but the learning is included in the education group. The aim is to innovate web-based learning tools and learning media in Nias dance engineering courses for students of Unimed FBS dance education program. This Learning and Media Learning Tool is to facilitate students in learning Nias Dance Engineering courses through the web scholoogy in the Sendratasik department. Innovations in learning devices ranging from RPS, LK, Assessment Rubrics, Teaching Materials, VCDs with No Tatema Mbola dance material.
\end{abstract}

Keywords: Learning Innovation, Nias Dance Engineering, Tari No Tatema Mbola.

\section{Introduction}

Education is not merely the science of curriculum or mere teaching methodology. But how can this curriculum work well according to the methodology that is run. One component of the education system is the curriculum, because the curriculum is a component of education that is used as a reference by the organizers, especially by lecturers and leaders because the curriculum as a reference must be able to grow to compensate for changing times. In the past few years, there have been several changes to the educational curriculum, solely aimed at adjusting to the times. The substitution is a form of innovation in the curriculum, so that the substance of the related substance has a better quality improvement than before. According to Law No.11 of 1989 concerning the national education system, the Curriculum is a set of plans and arrangements regarding the content and material of learning and the methods used as guidelines for the implementation of teaching and learning activities.

Curriculum and learning are intended as a particular idea, idea or action in the field of curriculum and learning that is considered new to solve educational problems. Curriculum innovation problems are related to the principle of relevance between learning materials and student needs, between the quality of learning and the users of graduates in the work field etc. Related to the quality of cognitive, affective, and psychomotor, while equity is related to opportunities and opportunities, then efficiency in terms of internal and external.

Learning curriculum is related to learning that uses media. One of the ways to achieve learning is through the media. Media comes from Latin is the plural form of Medium which literally means an intermediary or an introduction, namely an intermediary or an introduction 
to a message source with the recipient of the message. Scramm (1977) argues that learning media is a messenger technology that can be used for learning purposes. Hamid (2014) states that learning media is a component of delivery strategies that can be loaded with messages that will be conveyed to students, whether it be people, tools or materials. Briggs (1997) argues that learning media includes all the resources needed to communicate with students, this can be in the form of hardware such as computers, televisions, projectors and software used in hardware.

Based on the understanding of various sources about media, learning media can be understood as one that can deliver from a source in a planned manner so that a conducive learning environment occurs where the recipient can be done with the process effectively and efficiently. This learning media is based on the Nias Dance Engineering course which will be displayed on websites that will first be uploaded to the Internet network. This is an alternative by implementing the learning tools of the IQF curriculum in Nias Dance Engineering courses. Learning material is the core of the curriculum that serves as a means of achieving goals in the learning process. Learning material in the learning process occupies an important position in the learning process, it is because the teaching material is the material that will be delivered / presented. Without teaching materials, learning is impossible. Teaching materials must be in accordance with the objectives and competencies that are expected to achieve the expected learning.

\section{Problem}

We One of the reasons why this learning is displayed or uploaded via the web is to improve the ability of students to implement the learning tools of the IQF curriculum in Nias Dance Engineering courses. So that students can improve their technological understanding and creativity that can be channeled with critical and innovative thinking skills. This understanding of students is to improve the needs and resistance in learning. In this problem will reveal about matters related to thoughts about the constructs of character education and culture. Jagondzinski (1994) thinking in developing and disseminating knowledge that can help students in pursuing three core functions of education: Facilitating student learning, Encouraging personal development of students, Promote prosocial attitudes, habits, and behavior in students.

These three functions can help lecturers realize educational goals by giving important insight to students to develop learning, creative power in critical thinking. Currently the world of education is progressing with the advent of educational technology products that support the learning process in schools. One of them is Electronic Learning (E-Learning). According to e-learning experts, William Horton (2003) in his book Technology and Tools for ELearning defines e-learning as all uses or use of internet and web technology to create learning experiences. It can be simplified into all forms of use of internet-based technology to support the learning process, such as in school.

This e-learning based learning has several types. Among them are independent learning based on e-learning, conventional learning based on e-learning, combination learning based on e-learning, fast response e-learning, and e-learning based training guidance. This type of elearning has a very important role for student learning. Students and lecturers become aware of technology. The level of saturation in learning can be suppressed. The result is certainly 
more effective and efficient as a support for the learning process, without reducing the role of the lecturer in guiding students directly.

Learning with the media through technology whose dance material is No Tatema Mbola in Nias Engineering courses will mean providing stimulation of student intelligence, when dancing activities are designed based on Developmentally Appropriate Practice (Gestwicki, 2007). When learning through dance is designed with attention to the development and creative needs of students in an active, creative, effective and fun participatory atmosphere, learning to dance will be meaningful in developing students' intelligence in school.

Strongly encourage authors to use this document for the preparation of the camera-ready. Please follow the instructions closely in order to make the volume look as uniform as possible (Moore and Lopes, 1999).

Please remember that all the papers must be in English and without orthographic errors.

Do not add any text to the headers (do not set running heads) and footers, not even page numbers, because text will be added electronically.

For a best viewing experience the used font must be Times New Roman, on a Macintosh use the font named times, except on special occasions, such as program code (Section 2.3.7).

\section{Discussions}

Active learning as an innovation in the curriculum and learning can optimize the use of all the potential possessed by students, so that all students can achieve satisfying learning outcomes in accordance with the personal characteristics they have. Besides that, active learning is also intended to keep the attention of students / students to remain focused on the learning process. In learning with Active learning (active learning) empowerment of the left and right brain is very important. Thorndike (Bimo Wagito, 1997) proposed 3 laws of learning, namely 1 . law of readiness, namely the readiness of someone to do can facilitate the relationship between stimulus and response. 2. law of exercise, that is, with the repetitions that are always done, the relationship between stimulus and response will become smooth. 3 . the law of effect, namely the relationship between stimulus and response will be better if it can cause pleasant things, and this tends to be repeated.

Active learning basically strives to strengthen and facilitate the stimulus and response of students in learning, so that the learning process becomes fun, not boring for them. By providing an active learning strategy (active learning) in students can help their memory, so they can be delivered to the learning objectives successfully. This is less noticed in conventional learning. In the active learning method (active learning) each new subject matter must be associated with various previous knowledge and experiences. New learning material is actively provided with existing knowledge. In order for students to actively learn, teachers need to create appropriate strategies in such a way that students have high motivation to learn. (Mulyasa, 2004).

\section{A. Factors Affecting Innovation in Learning}

Innovations in the form of methods can have an impact on improvement, improve the quality of learning and as a new tool or way of solving problems encountered in educational activities. Thus new methods or new ways of implementing existing methods such as in the learning process can be an effort to improve the effectiveness of learning. Meanwhile, innovation in technology also needs to be considered given the many technological results that 
can be used to improve the quality of education, such as its use for learning technology, supervision procedures and management of educational information that can improve the efficiency of educational implementation. As for the factors that influence educational innovation, namely:

\section{Lecturer}

Lecturers as the spearhead in the implementation of education in universities are very influential parties in the teaching and learning process. The expertise and authority of a lecturer greatly determines the continuity of the teaching and learning process in the classroom and its effects outside the classroom. Lecturers must be able to bring their students to the goals to be achieved. There are several things that can shape the authority of the lecturer, among others, is the mastery of the material being taught, teaching methods that are in accordance with the situation and conditions of students, relationships between individuals, both with students and between fellow lecturers and other elements involved in the education process such as administrators, such as chairmen study program and administration and the surrounding community, the experience and skills of the lecturers themselves.

Thus, in the renewal of educational learning, the involvement of lecturers from planning of learning innovations to implementation and evaluation plays a huge role in the success of a learning innovation. Without involving them, it is very likely that they will reject the innovations introduced to them. This is as described previously, because they consider innovation that does not involve them is not theirs to be carried out, but instead they assume that they will disrupt the peace and smoothness of their duties. Therefore, in an innovation learning, the lecturer is the main and first involved because the lecturer has a broad role as an educator, as a parent, as a friend, as a motivator and so forth. (Wright, 1987).

\section{Students}

As the main object in the teaching and learning process, students hold a very dominant role. In the teaching and learning process, students can determine the success of learning through the use of intelligence, motor power, experience, will and commitment that arise in them without coercion. This can happen if students are also involved in the process of innovation in learning, by introducing them to the purpose of the change from planning to implementation, so that what they do is a shared responsibility that must be carried out consistently. The role of students in educational innovation is as important as the role of other elements, because students can be as recipients of lessons, giving material to their peers, instructions, and even as lecturers. Therefore, in introducing learning innovations to their application, students need to be invited or involved so that they not only accept and implement these innovations, but also reduce resistance as described previously.

\section{Curriculum}

Educational curriculum, the narrower the curriculum includes the teaching program and the tools are guidelines in the implementation of education and teaching in universities. Therefore the curriculum is considered as an inseparable part of the teaching and learning process so that in implementing this learning innovation, the curriculum plays the same role as other elements in education. Without the curriculum and without following the programs in it, then educational innovation will not run in accordance with the objectives of the innovation itself. 
Therefore, in the renewal of education, the change should be in accordance with changes in curriculum or changes in curriculum followed by renewal of education and it is not impossible that changes from both will go in the same direction as other elements in education. Without the curriculum and without following the programs in it, then this learning innovation will not run in accordance with the objectives of the innovation itself. Therefore, in the education discussion, the changes should be in accordance with curriculum changes or curriculum changes followed by educational renewal and it is not impossible that the changes from both will go in the same direction.

\section{Facilities}

Facilities, including educational facilities and infrastructure, cannot be ignored in the education process, especially in the teaching and learning process. In education reformation, of course facilities are things that influence the continuity of innovations that will be implemented. Without the existence of facilities, the implementation of educational innovations will certainly not work well. Facilities especially in teaching and learning facilities are essential in making changes and education reforms. Therefore, in implementing an educational innovation, facilities need to be considered. For example with the availability of buildings, benches, tables and so on.

\section{Social Scope of the Community}

In applying learning innovations, there are things that are not directly involved in these changes but can have an impact, both positive and negative, in the implementation of educational reform. People directly or indirectly, intentionally or not, are involved in education. Because, what you want to do in education is actually changing the community to be better, especially the community where the students come from. Without involving the surrounding community, learning innovations in education will certainly be disrupted, even damaging if not notified or involved. Community involvement in this innovation will instead help innovators and implement innovators in implementing educational innovations.

\section{B. Innovation in No Tatema Mbola Dance Learning}

Learning through dance requires a process by giving children the opportunity to be full of fun and fun. For students, creativity should be a preferred process, and don't expect too much creative, meaningful and useful products. If the lecturer is too fast demanding creative products that meet certain quality standards, this will reduce the fun and fun of children to be creative. In bringing up dance activities, it is giving freedom to students to carry out various explorations in order to create or express themselves creatively. Dance lecturers can help stimulate students to involve themselves in creative activities to help by seeking a fun and exciting atmosphere.

Dance is an art of motion that belongs to visual arts where it can be enjoyed through the senses of sight. Dance learning aims to train motor sensory, train its sensitivity and coordinate between movements and sounds, interpret experiences around it in motion and so on. Studying dance, is a means to recognize and preserve the types of dance that exist in the area. Dance from the beginning is a collective art, because in the process and framework of its form a place is formed by various other art disciplines, and dance as an art form is not only an expression of motion, but has brought with it a sense of rhythm that can provide a touch of 
aesthetic sense (Hidayat, 2005 ) The beauty of dance is not only the harmony of internal body movements in a room with certain music, but all expressions must contain dance intentions, so to judge something of dance, three aspects of wiraga, wirama, and wirasa are used.

\section{Tari NoTatema Mbola}

No Tatema Mbola can be interpreted as accepting betel nut, this dance is a social dance originating from the Nias region, North Sumatra. This dance depicts the joy and joy of the young people of Nias in establishing cooperation, harmony, intimacy and a sense of cohesiveness among them. The thing that is always maintained by the Nias community through the acceptance and giving of betel in social life as a symbol of the reception of incoming guests.

\section{Dance can educate students through daily activities}

Dance education can develop students' natural intelligence. Daily activities with the environment that can make students unite with their surroundings. In dance learning activities, methods are motivations that can be said to be the overall driving force in each person. If the method of learning dance is fun, naturally it will form a 'long term learning', which raises motivation to keep finding out, to continue to explore. Of course we also have to pay attention to each individual's talents of pleasure. And can't generalize that all children must master the same dance movement because that's where someone's uniqueness is (individual difference).

This power of thought and power is able to help develop intellectual intelligence. Because, with this movement can explore students' insight into various knowledge. Develop emotional intelligence and between personal or group. With groups of students, they will hone their emotions so that tolerance and empathy arise for others, comfortable and familiar with the group. The pleasure of motion exploration makes students repeat activities tirelessly. If we do everything we are glad we are free from pressure and what we produce will be better. Likewise pleasure in dance. We must stimulate the child's desire to explore, direct it without interfering, allowing students with their natural desire to learn and become independent. Every student and group will learn in their personal activities and learn to understand according to their unique needs and abilities. Joy arises in a specially created environment, the child's spontaneous freedom, responsibility, social and intellectual development will develop, which is what we know as lifelong education.

Howard Gardner in De Porter, Bobbi, \& Mike Hernacki stated that, a person will learn with all ability if he likes what he learns and he will feel happy to be involved in it. When creating active and meaningful learning situations for students (active learning). Students as learners are stimulated through learning activities to be able to build their knowledge through the active learning process they do them selves. Based on the foregoing, the intelligence of students is basically able to be optimized through dance art education which includes physical for motion, perception, power of thought and creativity in terms of processing motion.

\section{Conclusions}

Learning innovation is something that is important and must be owned or done by lecturers. This is because learning will be more alive and meaningful. Various innovations are 
expected to provide motivation to be creative for students to be more active. The strategy for implementing innovative learning is as follows: 1. Mastering learning theory. 2. Enrich understanding of learning methods. 3. Review the material taught. 4. Get to know the class conditions and students. 5. Make observations on previous learning. 6 Evaluation of previous learning. Make improvements to previous learning.

Changes in the concept of learning from conventional to e-learning should be related to learning strategies in academic development. Without this connection and development, the innovation will fail. If the learning innovation developed is successful, it is likely that students and students will further improve their abilities, making students interactively learn, making tasks more diverse and faster in their completion, and can develop strategies in terms of strengthening and evaluation. However, changing the concept of learning like this is not an easy thing to implement. This is acknowledged by some lecturers who have difficulty in implementing e-learning, but students also experience problems, especially in using computers. This will result in low learning progress achieved because learning with the concept of not face to face directly is not easy when compared to learning systems where students and educators can face to face directly. Innovation eventually becomes something that must be tried. 


\section{References}

[1] Brigg, J. L.: Instuction Design: Principle and Aplication. New York: Educational Tecnology Publication Inc (1997)

[2] Depdiknas.: PanduanPengembangan Silabus Mata PelajaranSeni Budaya Sekolah Menengah Pertama, Direktorat Jendral Pendidikan Dasar dan Menengah Pendidikan Sekolah Menengah Pertama:Jakarta (2006)

[3] Departemen Pendidikan dan Kebudayaan.: Peranan Masyarakat dalam Penyelenggaraan Taman Kanak-Kanak. Jakarta: Depdikbud.(1993)

[4] Dryden, Gordon dan Jeannette Vos.: Revolusi Cara Belajar Bagian. II Sekolah Masa Depan. Bandung: Kaifa.(2000)

[5] Frelberg, HJ. And Driscoll, A.: Universal Teaching Strategies. Boston: Allyn \& Bacon (1992)

[6] Gerlach, V.S \& Ely, D.: Teaching and Media A Systematic Approach. New Jersey: Prentice Hall(1980)

[7] Hamid, Abdul.: Teori Belajar dan Pembelajaran, Medan: Program Pascasarjana Universitas Negeri Medan(2014)

[8] Januari Jagondzinski dan mark Bracher Edito. : Psikoanalisis, Pendidikan dan Transformasi.(1994)

[9] Kamaril, C.: Konsep dan Sistem Pembelajaran kesenian Terpadu di Sekolah Dasar. Modul 2 Jakarta: Universitas terbuka Departemen Pendidikan dan kebudayaan.(1999)

[10] Keeton, M.T Best.: neline Instructional Practices: Report of Phase I of an Ongoing Study, Journal of Asynchronous Learning. Networks, Vol.8, No 2, 2004, pp.75-100 (2004)

[11] Mardiaatmaja, B.S.: Tantangan Dunia Pendidikan . Kanisius : Yogyakarta. Mashadi, Rizal, A.. Syaifruddin. (2006). Teknologi Informasidan Komunikasi untuk SMP/MTs kelas IX. Semarang: Aneka Ilmu(1986)

[12] Masunah, Juju \& Tati Narawati.: Seni dan Pendidikan Seni, Sebuah Bunga Rampai. Bandung: Pusat Penelitian dan Pengembangan Pendidikan Seni Tradisional (P4ST) UPI.(2003)

[13] Porter, Bobbi De and Mike Mermochi.: Quantum Leaming Membiasakan Belajar Nyaman dan Menyenangkan. Bandung: Kaifa(1999)

[14] Rahayu, Tuti.: Pendidikan Tari Sebagai Pemberi Identitas Dalam Upaya Mendorong Pengembangan Pribadi Siswa. Seminar Nasional Forum Asosiasi Prodi Pendidikan Seni Drama, Tari dan Musik. Medan: AP2SENI.(2015)

[15] Rahayu, Tuti.: The Paradise of North Nias Island, Medan, Indonesia. Pluralistic and Harmony Phenomenon of Life. Beau Bassin: LAP Lambert Academic Publishing.(2017)

[16] Ray S., I wayan. (2005). Seni Sebagai Identitas dan Perekat Bangsa. Makalah disampaikan dalam Orasi Ilmiah Universitas Trisakti Pada Seminar Tingkatkan Apresiasi Budaya Akademik dan Kedamaian dalam Masyarakat Bangsa, Jakarta 29 Nopember 2005.

[17] Scramm, Wilbur.: Big Media, Little Media, Tools and Tecnologies for Instruction. London: Sage Publication(1997)

[18] Supriadi, Dedi.: Membangun Bangsa Melalui Pendidikan.Bandung : Rosdakarya.(2004)

[19] Zuhdan Kun Prasetyo.: Pengembangan Perangkat pembelajaran Sains Terpadu Untuk Meningkatkan Kognitif, Ketrampilan Proses, Kreativitas serta Menerapkan Konsep Ilmiah Peserta Didik SMP. Program Pascasarjana UNY(2011) 